\title{
Relationship between age at first start and racing performance in Polish Thoroughbreds and Arab horses
}

\author{
MAGDALENA SOBCZYNSKA
}

Institute of Genetics and Animal Breeding, Polish Academy of Sciences, Jastrzębiec, Poland

\begin{abstract}
Genetic and phenotypic parameters for age at first start (AFS) and performance traits were estimated for Polish Thoroughbred and Arab horses using restricted maximum likelihood (REML) with an animal model. The traits representing a horse's racing performance were log of earnings (EA) and square root of number of starts (NS). Separate analyses per first racing season and whole career were carried out. The first racing season comprised 1759 Thoroughbreds and 1026 Arab horses. The racing results of whole racing career were available for 1319 Thoroughbreds and 815 Arab horses. The model accounted for fixed effects of birth year, month of birth, sex and trainer. The average of AFS of Thoroughbreds was 933.2 days for first racing season and 935.1 for whole career. The same AFS was observed at first season and whole career (about 1199 days) in Arab horses. Heritability estimates for AFS were rather low (0.15-0.21). All genetic correlations for Arab horses between age and performance traits varied from moderate to high (from -0.25 to -0.85 ). For whole career of Thoroughbreds, the genetic correlations had opposite signs compared to those observed in Arabs. Genetic correlation between AFS and EA in first racing season was very low in Thoroughbreds ( -0.07$)$, whereas high between AFS and NS (-1); the corresponding values for Arab horses were -0.25 and -0.76 . The opposite signs of phenotypic and genetic correlations ( $0.16 \mathrm{vs}-1$ and $-0.24 \mathrm{vs}$ 1 in first season and whole career, respectively) between AFS and NS in Thoroughbreds were observed. Phenotypic correlations between AFS and performance traits were close to zero for whole career while were rather low and moderate $(-0.22$ and -0.37$)$ for first season in Arab horses. Delay of the first start of Thoroughbreds is favourable from the point of view of future racing performance in whole career and has no effect on earnings in the first racing season. Arab horses beginning their career at a young age are start frequently and earn more money then those beginning their career later.
\end{abstract}

Keywords: racehorses, Thoroughbred, Arab horse, genetic parameters, age of first start, racing performance

\section{Zusammenfassung}

\section{Einfluss des Erststartalters auf Rennmerkmale bei Polnischen Vollblütern und Araberpferden}

Es wurden genetische und phänotypische Parameter für das Alter beim Erststart (AFS) und Rennmerkmale bei Polnischen Vollblut- und Araberpferden mit restricted maximum likelihood (REML) bei Nutzung des Tiermodells geschätzt. Als Rennleistung wurden die 
Merkmale Renngewinn (EA) und Anzahl der Starts (NS) von 1759 Vollblütern und 1026 Arabern bei den Erststarts bewertet. Für die Ergebnisse der Gesamtrennleistung konnten 1319 Vollblüter und 815 Araber ausgewertet werden. Im Modell wurden als fixe Effekte Geburtsjahr, Geburtsmonat, Geschlecht und Trainer berücksichtigt. Die Werte für AFS bzw. Gesamtrennzeit lagen beim Vollblut bei 933,2 bzw. 935,1 Tagen, bei Arabern bei 1198 Tagen. Die Heritabilitätsschätzwerte für AFS waren relativ niedrig bei $h^{2}=0,15$ bis 0,21 . Die genetischen Korrelationen zwischen Alter und Leistungen variierten bei Arabern stark zwischen $r_{g}=-0,25$ bis $-0,85$, jedoch für die Gesamtrennzeit verhielten sich diese Werte bei Vollblütern entgegengesetzt. Es werden weitere Ergebnisse der Parameterschätzung und Beziehungen zwischen den Merkmalen diskutiert. Ein späterer Erststart bei Vollblütern wirkte sich günstig auf die Rennmerkmale der Gesamtrennzeit aus, und es konnte kein Einfluss auf den Ertragsgewinn der Erstrennleistung nachgewiesen werden. Araber beginnen früher ihre Rennkarriere, starten häufiger und erzielen, wenn sie ein geringeres Erststartalter haben, höhere Renngewinne.

Schlüsselwörter: Rennpferd, Vollblut, Araber, genetische Parameter, Erststartalter, Rennleistung

\section{Introduction}

In Poland, official horse-racing is organized by Polish Jockey Club in huge majority at the race track in Warsaw. The races are arranged separately for Arab and Thoroughbred horses. Annually, about 500 Thoroughbred horses compete in about 350 races, whereas roughly 300 Arab horses compete in about 250 races. The Arab horses begin to race at the age of three years, which is one year later than for Thoroughbreds. The average distance for Arab horses is longer and horses are more heavily burdened. The number of starts per year (season) oscillate around 7 and 6 for Arab stallions and mares, respectively. The overall average number of races is similar for both sexes and amounted to 5.5 in Thoroughbreds.

Success within the Thoroughbred industry is measured in terms of racing performance. The main selection criterion in the Polish Arab horses has ever been »a bouquet", however the inclusion of information on racing performance in the selection of this breed as an additional criterion would result in a double breeding objective: conformation and success on the track. In Poland, Thoroughbreds and Arab horses are allowed to start racing after the first of May or June in the year when they reach two or three years of age, respectively. The biological age of young horses in the same age class may differ by several months, due to spanned foaling period. Moreover, age at first start may also be affected by the soundness and health of horses as well as intentions of horse owners and trainers. Racing season is short in Poland (usually from May to the end of November), then late starting horses have no opportunity to show their potential good racing ability and early starting foals may have some advantage compared to their contemporaries.

Summarized race records of horses over certain age classes are commonly used to estimate breeding values of racehorses in Poland and other countries. The number of starts influenced the probability of being placed and earning money. Theoretically, horses that started to compete at an younger age should have greater number of race starts during their racing career than 
horses that first raced at an older age. Practically, age at first start (as like as number of starts) is a trait strongly affected by environment (SAASTAMOINEN and OJALA 1991, RICARD and FORNET-HANOCQ 1997, MORE 1999). However, the ability to begin career early and show good performance at an early age is a desirable feature of horses in the trotting sport (SAASTAMOINEN and NYLANDER 1996a,b). Low starting age and ability to good performance at an early age are desirable traits in Thoroughbreds too, because they improve the economy of horse breeding by reducing costs of horse breeders and owners. Nowadays the quick returns of the investment is very important, and this is a reason for studying this trait also in Arab horses. Age at first start reflect time needed to reach physical maturity, but also health and soundness, which are important traits to be included in breeding programmes, in addition to race track performance traits (SAASTAMOINEN and NYLANDER 1996a). Moreover, age at first start had a significant impact on career longevity (BOURKE 1995, MORE 1999, HENLEY et al. 2006, SOBCZYNSKA 2007) and there was an unequivocal relation between the racing performance of the horse and the duration of its racing career. A young starting age enables earlier and more accurate selection of breeding animals. Relatively few studies were carried out to evaluate the effect of age at first start on racing performance in trotters (SAASTAMOINEN and NYLANDER 1996a,b) and Thoroughbreds (MOTA and OLIVEIRA 2000). The relationship between age at the beginning of the career and racing performance of Arab horses has not been reported previously. The purpose of this study was to estimate a heritability and the genetic and phenotypic correlations between age at first race and some racing performance traits in Thoroughbred and Arab horses in order to contribute to breeding programs for these breeds in Poland.

\section{Material and methods}

The study included the entire populations of Thoroughbred and Arab horses being performance-tested at the Polish racing tracks (Warsaw, Sopot, Stawiguda) during the years 1998-2004. The horses came from state studs, as well as private Polish and foreign breeders. Separate analyses per first racing season and whole career were carried out. The whole career data set does not include horses that were withdrawn from racing after the first season. The first racing season comprised 1759 Thoroughbreds and 1026 Arab horses. Due to small number of Thoroughbred horses continuing their career as 5 years old and older (6 for Arab horses), the annual records were summarized to represent the whole racing career from 2 through 4 years of age ( 3 through 5 for Arab horses). The racing results of whole racing career were available for 1319 Thoroughbreds and 815 Arab horses. The traits representing a horse's racing performance were log of earnings (EA) and square root of number of starts (NS). The age of the first start (AFS) was calculated in days from the date of birth to date of first race. Distribution of AFS and racing performance traits were examined for normality by measures of skewness, kurtosis, coefficient of variation and the Shapiro-Wilk statistic. In order to compare earnings, number of starts and age at first start of horses selected and withdrawn from racing after one year of competition analysis of variance was performed. The SAS software (1991) was used to perform descriptive analysis and to study the environmental factors on the trait analysed. The birth-month class, the sex, birth year and trainer of the horse were included in the model in order to account for their possible effects on AFS and performance traits. All fixed effects were significant for AFS for two breeds, sex was non- 
significant for EA and NS for first season of Thoroughbreds. The effect of birth-month on EA at first season and NS in whole career was non significant for Arab horses. Month of birth was also non-significant for NS in whole career for Thoroughbreds. The statistical model was tested for interactions between fixed effects, but the interactions were statistically nonsignificant. Therefore, these effects were dropped from the animal models, which were used to estimate genetic parameters.

The linear mixed model was as follows in matrix notation:

$$
y=X b+Z a+e
$$

where $y$ is a vector of summarized racing performance traits, and/or age at first start, $b$ is a vector of unknown fixed environmental effects, $a$ is a random vector of breeding values for the trait examined, and $e$ is a random vector of residual effects. $X, Z$ denotes incidence matrices relate the observations to corresponding fixed and random effects. The model accounted for fixed effects of birth year (1996-2002 and 1995-2001 for Thoroughbreds and Arab horses, respectively), month of birth (January, February, March, April, May and later), sex (male, female; 20 Thoroughbred's geldings were classified together with mares), trainer (36 and 32 depending from data set for Thoroughbreds and Arab horses respectively and trainers who trained less than 6 horses were grouped into one class). The number of observations for each fixed effect level is given in Table 1. The similar proportions of males and females as well horses born in different months were observed in the first racing season and whole career for two breeds.

Table 1

Number of observations for each fixed effect level for first racing season and whole racing career for two breeds. The effect strainer contains range of the observations

Anzahl der Beobachtungen der fixen Effekte für die erste Rennsaison und die ganze Rennkarriere bei beiden Rassen.

\begin{tabular}{|c|c|c|c|c|}
\hline \multirow[t]{3}{*}{ Fixed effect } & \multicolumn{4}{|c|}{ Number of observation, $\%$} \\
\hline & \multicolumn{2}{|c|}{ Thoroughbreds } & \multicolumn{2}{|c|}{ Arabs } \\
\hline & first season & whole career & first season & whole career \\
\hline \multicolumn{5}{|l|}{ Birth year } \\
\hline 1995 & & & $79 \quad(7.7)$ & $79 \quad(9.7)$ \\
\hline 1996 & $233(13.2)$ & $233(17.7)$ & $165(16.1)$ & $165(20.2)$ \\
\hline 1997 & 300 (17.1) & $300(22.7)$ & $183(17.8)$ & $183(22.5)$ \\
\hline 1998 & 300 (17.1) & $300(22.7)$ & $187(18.2)$ & $187(22.9)$ \\
\hline 1999 & $256(14.6)$ & $256(19.4)$ & 201 (19.6) & $201(24.7)$ \\
\hline 2000 & $230(13.0)$ & $230(17.4)$ & $211(21.6)$ & \\
\hline 2001 & $268(15.2)$ & & & \\
\hline 2002 & $172(9.8)$ & & & \\
\hline \multicolumn{5}{|l|}{ Month of birth } \\
\hline January & $313(17.8)$ & $235(17.8)$ & $229(22.3)$ & $190(23.3)$ \\
\hline February & $417(23.7)$ & $316(24.0)$ & $263(25.6)$ & $206(25.3)$ \\
\hline March & $474(26.9)$ & $343(26.0)$ & $238(23.2)$ & $191(23.4)$ \\
\hline April & $380(21.6)$ & $282(21.4)$ & $178(17.3)$ & $137(16.8)$ \\
\hline May and later & $175(10.0)$ & $143(10.8)$ & $118(11.5)$ & 91 (11.2) \\
\hline \multicolumn{5}{|l|}{ Sex } \\
\hline male & $872(49.6)$ & $665(50.4)$ & 571 (55.7) & $460(56.4)$ \\
\hline female & $887(50.4)$ & 654 (49.6) & 455 (44.3) & 355 (43.6) \\
\hline Trainer & $5-257$ & $5-182$ & $5-112$ & $5-90$ \\
\hline
\end{tabular}


The appropriate models were used to estimate heritabilities and phenotypic and genetic correlations for the traits within first racing season and a horse's whole career. The variance components were evaluated using REML procedure as implemented in the program VCE (GROENEVELD 1998).

When known, pedigree information from minimum of three generations- the animal, parents and grandparents was used in the construction of the additive relationship matrix (3981 animals for Thoroughbreds and 2541 for Arab horses). The average number of progeny per sire were 5.7 and 4.4 for Thoroughbreds and Arab horses respectively, whereas the average number of progenies per dam was the same for both breeds and amounted to 1.5 .

\section{Results and discussion}

Parameters of trait distributions are presented in Table 2 and 3 for Thoroughbreds and Arab horses, respectively.

Table 2

Distribution parameters of studied traits for Thoroughbreds

Beschreibung der untersuchten Merkmale bei Vollblutpferden

\begin{tabular}{lcccccc}
\hline & \multicolumn{2}{c}{ AFS } & \multicolumn{2}{c}{ EA } & \multicolumn{2}{c}{ NS } \\
& first & whole & first & whole & first & whole \\
& season & career & season & career & season & career \\
\hline No. of horses & 1759 & 1319 & 1759 & 1319 & 1759 & 1319 \\
Average & 933.2 & 935.1 & 6.8 & 8.0 & 1.8 & 3.0 \\
Minimum & 769 & 769 & 0 & 0 & 1 & 1.4 \\
Maximum & 1363 & 1363 & 11.0 & 13.1 & 3.9 & 9.1 \\
Standard deviation & 101.1 & 105.6 & 3.0 & 2.8 & 0.5 & 1.1 \\
Coefficient of variation & 10.8 & 11.3 & 44.5 & 34.7 & 28.7 & 35.8 \\
Skewness & 1.54 & 1.49 & -1.48 & -1.89 & 0.45 & 0.45 \\
Kurtosis & 2.19 & 1.86 & 0.89 & 3.12 & 0.38 & 1.21 \\
\hline
\end{tabular}

AFS age at first start in days, EA log of earnings, NS square root of number of starts

Table 3

Distribution parameters of studied traits for Arab horses

Beschreibung der untersuchten Merkmale bei Arabern

\begin{tabular}{lcccccc}
\hline & \multicolumn{2}{c}{ AFS } & \multicolumn{2}{c}{ EA } & \multicolumn{2}{c}{ NS } \\
& $\begin{array}{l}\text { first } \\
\text { season }\end{array}$ & $\begin{array}{l}\text { whole } \\
\text { career }\end{array}$ & $\begin{array}{l}\text { first } \\
\text { season }\end{array}$ & $\begin{array}{l}\text { whole } \\
\text { career }\end{array}$ & $\begin{array}{l}\text { first } \\
\text { season }\end{array}$ & $\begin{array}{l}\text { whole } \\
\text { career }\end{array}$ \\
\hline No. of horses & 1026 & 815 & 1026 & 815 & 1026 & 815 \\
Average & 1198.7 & 1198.8 & 7.1 & 7.6 & 2.4 & 3.1 \\
Minimum & 1048 & 1048 & 0 & 0 & 1 & 1.4 \\
Maximum & 1412 & 1412 & 11.1 & 12.2 & 4.0 & 6.8 \\
Standard deviation & 57.9 & 58.6 & 2.9 & 2.8 & 0.6 & 1.2 \\
Coefficient of variation & 4.8 & 4.9 & 40.4 & 37.5 & 24.6 & 37.2 \\
Skewness & 0.48 & 0.50 & -1.77 & -1.80 & -0.47 & 0.36 \\
Kurtosis & 0.54 & 0.57 & 1.80 & 2.40 & -0.08 & -0.27 \\
\hline
\end{tabular}

AFS age at first start in days, EA log of earnings, NS square root of number of starts 
The average of the age at first race of Thoroughbreds was 933.2 days for first racing season. Horses continuing their racing career after the first season tended to be a little bit older (935.1 days) than those before selection and one year of competition. A higher age at first start (1 077 days) was found by MOTA and OLIVEIRA (2000) in Brazilian Thoroughbreds. As the Arab horses begin to race at the age of three years, which is one year later than for Thoroughbreds, age at first race was higher and amounted to 1198.8 days. The same age of first start was observed in Arab horses at first season and whole career.

The coefficient of variation for age at first start was rather low and twice higher in Thoroughbreds ( $11 \%$ ) than in Arab horses (5\%). The coefficients of variation are lower than the ones reported by SAASTAMOINEN (1991) in Finnhorse and Standardbred trotter (20\%) and MOTA and OLIVEIRA (2000) in Brazilian Thoroughbred racehorses (15.6\%). In this study about $12 \%$ of the Thoroughbreds had their first start at the age of three years old. One can suppose that they were more likely to have been born in later months during the year. However, those animals did not differ in this respect from horses that began their career at an earlier age - the proportion of horses born in different months was almost the same (SOBCZYNSKA 2006). The reasons for the higher variation in age at first start in Thoroughbreds may vary. Some owners and trainers may want to delay the competition, and so save their horses to allow for a longer career, because training regimen for young Thoroughbreds is responsible for musculoskeletal injuries particularly during the early stages of training (MORE 1999, VERHEYEN et al. 2007). The delay in the first start of three year olds was probably caused by health problems, skeletal immaturity or lack of talent. At all data sets, the mean coefficient of skewness was 1.51 and 0.49 for Thoroughbreds and Arab horses, respectively. There are no physiologic limits that prevent a horse from starting at late age. Thus, for a frequency distribution curve of ages at first start, it is sensible that the upper tail is longer than the lower tail. Positive kurtosis indicates that the tails are relatively long, particularly in Thoroughbreds, compared to a normal distribution with the same standard deviation.

There were greater difference between means of earnings, coefficients of variation, skewness and kurtosis of the first season and whole career in Thoroughbreds than in Arab horses. The selection pressure on racing performance in Thoroughbreds is stronger than in Arab horses, because the most emphasis in breeding Arab horses is put on conformation and less attention is paid to racing success. The distribution of earnings had a small negative coefficient of skewness, reflecting the grater difficulty of winning high prizes compared with low ones, especially after the first season of racing, where due to selection, competition became more difficult. Distribution parameters of square root of number of starts were similar in both breeds except the first season of racing. Average number of starts at first season was lower in Thoroughbreds ( 3.3 and 1.8 for normal and transformed scale, respectively) than in Arab horses (5.8 and 2.4).

$440(25 \%)$ and $211(20 \%)$ Thoroughbred and Arab horses, respectively were withdrawn from racing after first racing season. There were no statistically significant differences in the earnings, number of starts and age at first start between Arab horses withdrawn from racing after first racing season and selected to the next one. Thoroughbreds which earned more money and had a greater number of starts during their first racing season had a higher probability to stay at the racecourse for the next season. Differences between log of earnings of horses withdrawn from racing (6.2) and selected (7.0) and between square root of number 
of starts (1.7 vs 1.8) were statistically significant. Difference between horses withdrawn from racing and selected in the age of first start was nonsignificant.

The heritability estimates for age at first start were low and moderate (Table 4), being lower in Thoroughbreds for first racing season than in Arab horses.

Table 4

Heritability estimates and respective standard error $\left(\mathrm{h}^{2} \pm \mathrm{SE}\right)$ for age at first start obtained from one- and two traits analysis

Heritabilitätsschätzwerte für das Erststartalter

\begin{tabular}{lccc}
\hline & $\begin{array}{c}\text { One trait analysis } \\
\text { AFS }\end{array}$ & EA & Two traits analysis \\
\hline Thoroughbreds & & & \\
AFS (first racing season) & $0.15 \pm 0.04$ & $0.16 \pm 0.05$ & $0.13 \pm 0.04$ \\
AFS (whole career) & $0.21 \pm 0.07$ & $0.27 \pm 0.07$ & $0.25 \pm 0.06$ \\
Arab horses & & & \\
AFS (first racing season) & $0.19 \pm 0.06$ & $0.19 \pm 0.06$ & $0.20 \pm 0.06$ \\
AFS (whole career) & $0.19 \pm 0.07$ & $0.19 \pm 0.08$ & $0.22 \pm 0.08$ \\
\hline
\end{tabular}

AFS age at first start, EA log of earnings, NS square root of number of starts

The difference between heritability estimates obtained by one and two- traits analysis was small in Arab horses, but larger in Thoroughbreds. Compared to first racing season, the estimates of heritability were on the same level as obtained in whole career in Arab horses whereas difference is noticeable in Thoroughbreds. The heritabilities were considerably higher than reported by SAASTAMOINEN and NYLANDER (1996a) obtained by the REML sire model in Standardbred and Finnhorse trotters. The heritability for age at first race in Thoroughbreds agree with those reported in a previous study by SAASTAMOINEN and NYLANDER in Standardbreds (1996b) and calculated with an animal model and derivativefree REML method. SAASTAMOINEN (1991) found similar heritability (0.20) for age at the beginning of the career of trotters, associated with large standard errors. On the other hand, estimates of heritability for both breeds were higher than estimates of SAASTAMOINEN and OJALA (1991) in trotters. However, the results of SAASTAMOINEN and OJALA (1991) and SAASTAMOINEN (1991) are not fully comparable with those of the present study, because in their studies, age was determined in full years. MINKEMA (1975) found higher heritabilities (0.20 and 0.27) for precocity, determined as money earned as 2- to 3-year-olds expressed as a percentage of total earnings. BODÓ (1997) expressed early maturity of Thoroughbred horses by relationship between 2-year handicap weight and the best one in the life time performance. The heritability of this trait agree with those obtained in present study for Arab horses and whole career of Thoroughbreds (0.21). From a genetic improvement point of view the age of first start is difficult to be included in the selection programme in Thoroughbreds due to low heritability estimates. The early maturity measured by age at first start can not be used as a selection criterion, but it may be important when the intensity of the training is in question.

Heritability of number of starts, resulting from two-traits analysis was very low, especially for Thoroughbreds (0.02). Heritability for this trait was relatively higher in Arab horses (0.14 and 0.19 for first racing season and whole career, respectively). It seems that the number of starts is depending more on the month of birth and strategy of the trainer than on any 
genetic background. In contrast with the current study PIKUŁA and GRZESIAK (2003) and GRZESIAK and PIKUŁA (2003) reported the higher heritability estimates for number of starts in Thoroughbreds than in Arab horses. Estimates of heritability for number of starts in Thoroughbreds were considerably lower than those reported by BODÓ (1997), SVOBODOVA et al. (2005), PARK and LEE (1999) and GRZESIAK and PIKUŁA (2003). Nevertheless, the heritability estimates of number of starts in Arab horses agree with those obtained by early mentioned authors.

Heritability of earnings obtained from two-trait analysis in Thoroughbreds ( 0.12 and 0.14 for first race season and whole career respectively) and Arab horses (0.27 and 0.29) did not differ considerably from those obtained for similar criteria in these breeds (LANGLOIS 1996, SOBCZYNSKA and KOWNACKI 1997, BUGISLAUS et al. 2004, SVOBODOVA et al. 2005, EKIZ et al. 2005, EKIZ and KOÇAK 2005)

In Table 5 the genetic and phenotypic correlations between age at the first race and performance traits are presented. The genetic correlations obtained for two breeds were associated with large standard errors, though those observed in Arab horses were larger. All genetic correlations between age at first start and earnings were on a higher level in Arab horses than in Thoroughbreds, whereas for number of starts is just the opposite. Genetic correlation between age at first start and earnings in first racing season was very low in Thoroughbreds $(-0.07)$, whereas moderate $(-0.25)$ in Arab horses. The corresponding phenotypic correlations were found to be similar in two breeds $(-0.21$ vs -0.22 in Thoroughbreds and Arab horses, respectively) and of lower absolute values than those reported previously by SAASTAMOINEN and OJALA (1991) and SAASTAMOINEN and NYLANDER (1996b) in trotters. The opposite sign of genetic correlations between age at first start and number of starts in first racing season (-1) and whole career (1) in Thoroughbreds make analysis difficult and may indicate that number of starts of young horses and horses with longer career are not the same traits.

Table 5

Genetic and respective standard error $\left(r_{g} \pm S E\right)$ and phenotypic $\left(r_{p}\right)$ correlations between age at first start and performance traits in Thoroughbred and Arab horses

Genetische und phänotypische Korrelationen zwischen Erststartalter und Rennmerkmalen bei Vollblut und Arabern

\begin{tabular}{|c|c|c|c|c|}
\hline & $r_{g}$ & $r_{p}$ & $r_{g}$ & $r_{p}$ \\
\hline \multicolumn{5}{|l|}{ Thoroughbred } \\
\hline First season & $-0.07( \pm 0.17)$ & -0.21 & $-1( \pm 0.02)$ & 0.16 \\
\hline Whole career & $0.25( \pm 0.17)$ & -0.41 & $1( \pm 0.02)$ & -0.24 \\
\hline \multicolumn{5}{|l|}{ Arab } \\
\hline First season & $-0.25( \pm 0.18)$ & -0.22 & $-0.76( \pm 0.14)$ & -0.37 \\
\hline Whole career & $-0.57( \pm 0.26)$ & -0.06 & $-0.85( \pm 0.19)$ & -0.05 \\
\hline
\end{tabular}

EA log of earnings, NS square root of number of starts

Inter-breed differences regarding the relationship between age at first start and log of earnings in whole career can be seen. While genetic correlation is positive in Thoroughbreds (0.25), in Arab horses is moderately high and negative (-0.57). The same pattern appears when number of start in whole career is considered but genetic correlations were on the 
higher level ( 1 and -0.85 for Thoroughbreds and Arab horses, respectively). Arab horses beginning their career at a young age are start frequently and earn more money then those beginning their career later. The fact, that early starters maintained their advantage beyond the first racing season implies that they were superior horses. However, the superior career performance of horses starting to race at a young age may be partly a result of the skilled selection by managers, as found SAASTAMOINEN and NYLANDER (1996b). High genetic correlation between age at first start and number of starts in whole career (-0.85) suggests that these traits have similar genetic base. PHYSICK-SHEARD (1986) and SAASTAMOINEN and OJALA (1994) found that trotters starting their career early are superior to other race horses, whereas MINKEMA (1975) found no relationship between precocity and racing performance in Dutch trotters. According to MOTA and OLIVEIRA (2000) age at first start had no effect on number of starts of Brazilian Thoroughbreds $\left(r_{q}=-0.06\right)$ and some others performance traits like number or percentage of placements in top five, percentage of victories $\left(r_{g}\right.$ amounted from -0.06 to 0.1$)$. Delay of the first start of Thoroughbreds is favourable from the point of view of future racing performance in whole career and has no effect on earnings in the first racing season. Similar results have obtained MOTA and OLIVEIRA (2000) who reported positive genetic correlation between age at first start and number of victories $\left(r_{g}=0.24\right)$, which is directly related to amount of money won in a race. The opposite signs of phenotypic and genetic correlations ( 0.16 vs -1 , respectively) between age at first start and number of starts in Thoroughbreds can result from the greatest allowable number of starts of three-year olds than two-year-olds in first racing season. Due to low heritability estimates of number of starts and age at first start, phenotypic correlation between two traits result from environmental effects mainly. The difference among phenotypic correlations between age at first start and earnings $(-0.21)$ and number of starts (0.16) in Thoroughbreds in first season indicates that horses began their career at earlier age had a higher earnings, but not higher frequency of starts than horses starting to compete at an older age. It is possible that trainers easier identify racing abilities of early starters and choose the level of races according to level of their horses to optimize their chances on earnings. MORE (1999) found that age of first start of Australian Thoroughbreds ( 2 year olds in comparison to all other racing cohorts) were each significantly associated with increased likelihood of high performance during the first year of racing. When compare the average age of first start of horses in the first season (933.2) and whole career (935.1) it is possible to assume, that some horses with young starting age were withdrawn from racing after one year of racing, probably as a result of health problems or musculoskeletal injuries and low performance. On the other hand, the hazard ratio for career duration of three-year-old vs two-year-old Thoroughbred horses (4.5) reported by SOBCZYNSKA (2007) showed, that those that began their career at earlier age had a higher probability of a long racing life. According to SOBCZYNSKA (2006) trainer has no effect on age at first start of Arab horses whereas Thoroughbreds trained by professional trainers started racing significantly earlier then horses trained by nonprofessional ones. It can be supposed, based on "unfavorable« genetic correlations for Thoroughbreds, that earnings and starting frequency in whole career are more dependent on environmental effects such as the intensions of their trainers and owners than for Arab horses, as indicated by low heritability estimates. 
In conclusion, direct selection for age at first start does not seem to be necessary, however the heritability of this trait (0.2) makes this selection possible. Age of first start may be a valuable measure of soundness and physical resistance, especially for Arab horses compared to Thoroughbreds due to higher genetic correlation with earnings and more stable values in the first season and whole racing career. In general, young age at first start was associated with superior performance in Arab horses whereas delay of the first start of Thoroughbreds is favourable from the point of view of future racing performance in whole career. Due to low number of observations and large standard errors, the estimates are very indicative and only of little value as estimates of parameter values.

\section{References}

Bodó I (1997) Practical use of heritability estimates of primary and secondary traits of Thoroughbred racehorses. 48th Annual Meeting of EAAP, 25-8 August, Vienna, Austria

Bourke JM (1995) Wastage in Thoroughbreds. Animal Seminar, Equine Branch, New Zealand Veterinary Association. Foundation for Continuing Education, no.167, 17-119

Bugislaus AE, Roehe R, Uphaus $\mathrm{H}$, Kalm E (2004) Development of genetic models for estimation of racing performances in German Thoroughbreds. Arch Tierz 47, 505-16

Ekiz B, Koçak Ö (2005) Phenotypic and genetic parameter estimates for racing traits of Arabian horses in Turkey. J Anim Breed Genet 122, 349-56

Ekiz B, Koçak Ö, Yilmaz A (2005) Phenotypic and genetic parameter estimates for racing traits of Thoroughbred horses in Turkey. Arch Tierz 48, 121-9

Groeneveld E (1998) VCE4 user's guide and reference manual version 1.1. Institute of Animal Husbandry and Animal Behaviour, Federal Agricultural Research Centre (FAL), Neustadt, Germany

Grzesiak W, Pikuła R (2003) Analysis of racing performance measures for Thoroughbred horses. Zesz Nauk Przeg Hod 68, 5, 235-40 [in Polish]

Henley WE, Rogers K, Harkins L, Wood JL (2006) A comparison of survival models for assessing risk of racehorse fatality. Prev Vet Med 74, 1, 3-20

Langlois B (1996) A consideration of the genetic aspects of some current practices in Thoroughbred horse breeding. Ann Zootech 45, 41-51

Minkema D (1975) Studies on the genetics of trotting performance in Dutch trotters. I. The heritability of trotting performance. Ann Gen Sel Anim 7, 99-121

More $S$ (1999) A longitudinal study of Australian racing Thoroughbreds: performance during the first years of racing. Aust Vet J 77, 2, 105-13

Mota MDS, Oliveira HN (2000) Precocity and performance in Brazilian Thoroughbreds. Arch Zootec 49, 188, 497-500

Park KD, Lee KJ (1999) Genetic evaluation of Thoroughbred racehorses in Korea. Kor J Anim Sci 41, 2, 135-40

Physick-Sheard PW (1986) Career profile of the Canadian Standardbred. II. Influence of age, gait and sex upon number of races, money won and race times. Can J Vet Res 50, 457-70

Pikuła R, Grzesiak W (2003) Analysis of racing performance measures for pure-bred Arab horses. Zesz Nauk Przeg Hod 68, 5, 229-34 [in Polish]

Ricard A, Fournet-Hanocq $F$ (1997) Analysis of factors affecting length of competitive life of jumping horse. Genet Sel Evol 29, 251-67

Saastamoinen MT, Ojala MJ (1991) Estimates of genetic and phenotypic parameters for racing performance in young trotter. Acta Agric Scand 41, 427-36

Saastamoinen MT, Ojala MJ (1994) Influence of different combinations of racing years on early career performance in trotters. Acta Agric Scand Sect A Anim Sci 44, 208-13 
Saastamoinen MT (1991) Factors affecting age at onset of breaking, training, qualifying and first start in Finnish trotters. Acta Agric Scand 41, 137-45

Saastamoinen MT, Nylander A (1996a) Genetic and phenotypic parameters for age and speed at the beginning of racing career in trotters. Acta Agric Scan Sect A Anim Sci 46, 39-45

Saastamoinen MT, Nylander A (1996b) Genetic and phenotypic parameters for age at starting to race and racing performance during early career in trotters. Livest Prod Sci 45, 63-8

SAS/STAT 9.1 Statistical Analysis System (1999) User's guide. SAS Institute Inc, Cary, NC, USA

Sobczynska M, Kownacki M (1997) Genetic aspects of racing performance in the Polish pure bred Arab horses. I. Genetic parameters. J Appl Genet 38, 2,179-86

Sobczynska M (2006) Factors affecting age at first start in Thoroughbreds and Arab horses. Prace Mat Zoot 63, 91-9 [in Polish]

Sobczynska M (2007) The effect of selected factors on length of racing career in Thoroughbred racehorses in Poland. Anim Sci Pap Rep 25, 3, 131-41

Svobodova S, Blouin C, Langlois B (2005) Estimation of genetic parameters of Thoroughbred racing performance in the Czech Republic. Anim Res 54, 499-509

Verheyen KLP, Price JS, Wood JLN (2007) Fracture rate in Thoroughbred racehorses is affected by dam age and parity. Vet J 174, 295-301

Received 10 July 2009, accepted 12 October 2010.

Corresponding author:

MAGDALENA SOBCZYNSKA

email:m.sobczynska@ighz.pl

Institute of Genetics and Animal Breeding, Polish Academy of Sciences, Jastrzębiec, ul. Postępu 1, 05-552 Wólka Kosowska, Poland 